\title{
PENGARUH SUPLEMENTASI DL-METIONIN DAN L-LISIN HCL PADA PAKAN STANDAR KAFETARIA TERHADAP BERAT BADAN, ORGAN DALAM DAN ORGAN REPRODUKSI AYAM KAMPUNG FASE PULLET
}

\author{
Effect of Supplementation of DL-Methionine and L-Lysine HCl Into Diets Based on Cafeteria \\ Standards on The Body Weight, Internal Organ and Reproductive Organ of \\ Native Chickens at Pullet Phase
}

\section{Charles V. Lisnahan ${ }^{1}$, Wihandoyo ${ }^{2}$, Zuprizal $^{2}$, Sri Harimurti ${ }^{2}$}

${ }^{1}$ Faculty of Agriculture, Universitas Timor

Sasi, Kefamenanu City, North Timor Tengah Regency, East Nusa Tenggara

${ }^{2}$ Faculty of Animal Husbandry, Universitas Gadjah Mada

Bulaksumur, Caturtunggal, Kec. Depok, Kabupaten Sleman, Daerah Istimewa Yogyakarta 55281

Email : charleslisnahan@yahoo.co.id

\begin{abstract}
The aim of this study was to determine the effect of the supplementation of dl-methionine and l-lysine $\mathrm{HCl}$ to diet based on cafeteria standards of native chickens on body weight, internal organs and reproductive organs of native chicken at pullet phase. A total of 128 fourteen weeks-old native chickens were used in this study. The native chickens were divided into 4 treatments with 4 replications. The dietary treatments were: $T_{0}$ (ration based on cafeteria standard), $T_{1}$ (ration based on protein standard of NRC), $T_{2}$ (cafeteria ration $+0.09 \%$ DL-Methionine $+0.22 \%$ L-Lysine $\mathrm{HCl}$ ), $\mathrm{T}_{3}$ (cafeteria ration $+0.19 \% \mathrm{dl}$ methionine+0.42\% l-lysine $\mathrm{HCl}$ ). The data collected were body weight, liver and bile, pancreas, gizzard, testicular and ovary weight of native chickens aged 20 weeks. The result of this study for $T_{0}, T_{1}, T_{2}$ and $T_{3}$ showed that body weight of chickens were 1418.60; 1431.59; 1503.88 and $1556.41 \mathrm{~g} / \mathrm{bird}$, liver and bile weights were $22.44 ; 21.79 ; 24.49$ dan $25.93 \mathrm{~g} / \mathrm{bird}$, pancreas weights were $2.33 ; 2.28 ; 2.50$ and $2.70 \mathrm{~g} / \mathrm{bird}$, gizzard weight were $25.31 ; 23.91 ; 25.38$ and $26.86 \mathrm{~g} / \mathrm{bird}$, testicular weight were $3.66 ; 3.86 ; 9.55$ and 9.46 g/bird, testicular volume were $3.81 ; 3.38 ; 9.13$ and 9.16 and ovary weight were $1.12 ; 1.32 ; 3.14$ and 4.61 g/bird, respectively. The results showed that supplementation of DL-Methionine and L-Lysine $\mathrm{HCl}$ gave significantly effect $(P<0.05)$ upon body weight, liver and bile weight, pancreas weight, testicular weight and volume and ovary weight, but it did not effected to gizzard weight. It can be concluded that supplementation of $0.27 \%$ dl-methionine and $0.79 \%$ l-lysine $\mathrm{HCl}$ increase body weight, internal organs weight and reproductive organs weight of native chickens.
\end{abstract}

Keywords: Cafeteria, DL-Methionine, L-Lysine HCl, Native Chicken, Supplementation.

\section{PENDAHULUAN}

Produktivitas dan reproduktivitas ayam kampung sangat ditentukan oleh faktor pakan. Selama ini pemberian pakan pada ayam kampung didasarkan oleh ratio energi-protein dan ratio kalsium-fosfor. Seperti pada ayam broiler dan petelur, kebutuhan nutrien harus didasarkan pada keseimbangan makro dan mikro nutrien. Pada ayam kampung, hal ini belum dilakukan baik pada fase starter, grower maupun pullet. Hasil penelitian dengan pakan kafetaria (free choice feeding) didapatkan bahwa kebutuhan nutien ayam kampung adalah 2987,31 kcal/kg ME, $13,20 \%$ protein kasar, $6,48 \%$ lemak kasar, $7,73 \%$ serat kasar, $0,02 \%$ metionin, $0,03 \%$ lisin, $1,26 \%$ kalsium dan 0,60\% fosfor (Lisnahan, 2018).
Berdasarkan rekomendasi NRC (1994), kebutuhan nutrien seperti asam amino metionin dan lisin untuk ayam petelur putih fase pullet adalah 0,20 dan $0,45 \%$. Asam amino metionin dan lisin merupakan 2 asam amino pembatas utama pada pakan berbasis jagung dan kedelai untuk ayam broiler. Hal ini memungkinkan apabila ayam kampung diberikan tambahan asam amino metionin dan lisin dapat meningkatkan kinerjanya. Bronstein dan Lepstein (1975) melaporkan sebelumnya bahwa pakan ayam broiler yang mengandung $19.1 \%$ protein kasar, apabila dilengkapi dengan metionin akan menghasilkan pertumbuhan dan efisiensi penggunaan pakan yang sama dengan pakan yang mengandung $23 \%$ protein kasar. Defisiensi metionin dapat menyebabkan protein tubuh rendah, kadar lemak tubuh tinggi dan konsumsi 
pakan berlebih yang mengakibatkan deposisi lemak (Kartikasari et al., 2001). Suplementasi lisin pada pakan yang kekurangan lisin dapat menyeimbangkan asam amino yang berfungsi untuk memodifikasi jumlah protein yang disintesis dan didegradasi pada ayam (Pesti et al., 2005). Leeson dan Summers (2001) menyatakan bahwa pemberian lisin sebanyak $1,25 \%$ sampai ayam berumur 42 hari, dan sebanyak $1,06 \%$ pada periode finisher dapat meningkatkan pertumbuhan dan perkembangan dada ayam broiler. Ayam yang mengalami defisiensi asam amino lisin akan mengalami penurunan pertumbuhan dan akresi protein, yang berpengaruh drastis terhadap perkembangan otot dada (Selle et al., 2007).

\section{MATERI DAN METODE}

Penelitian ini dilakukan di kandang Laboratorium Ternak Unggas Fakultas Peternakan, UGM Yogyakarta selama 6 minggu.
Materi penelitian adalah ayam kampung umur 14 minggu sebanyak 128 ekor, tepung jagung kuning, bekatul, bungkil kedelei, tepung ikan, kapur dan premix vitamin, dl-metionin dan 1-lisin $\mathrm{HCl}$. Kandang yang digunakan adalah kandang panggung kawat 16 buah ukuran 2 x 1 x 0,5 meter. Ayam kampung dibagi dalam 16 unit kandang, masing-masing unit 8 ekor dengan perlakuan $\mathrm{T}_{0}$ (pakan kontrol sesuai standar kafetaria, tanpa dlmetionin dan 1-lisin $\mathrm{HCl}$ ); $\mathrm{T}_{1}$ (pakan dengan standar protein menurut NRC); $\mathrm{T}_{2}$ (pakan dengan suplementasi dl-metionin 0,09\% dan 1-lisin $\mathrm{HCl}$ $0,22 \%$ ); $\mathrm{T}_{3}$ (pakan dengan suplementasi DLMetionin 0,09\% dan L-Lisin $\mathrm{HCl}$ 0,42\%). Komposisi pakan perlakuan tersaji pada Tabel 1 . Parameter penelitian yang diamati adalah: berat badan, berat hati dan empedu, berat pancreas, berat gizzard, berat dan volume testis dan berat ovarium. Data dianalisis dengan analisis variansi dan dilanjutkan dengan uji Duncan menggunakan software Statistical product and Service Solutions (SPSS) 21.

Tabel 1. Susunan dan kandungan nutrien pakan

\begin{tabular}{|c|c|c|c|c|}
\hline \multirow{2}{*}{ Bahan pakan } & \multicolumn{4}{|c|}{ Perlakuan } \\
\hline & $\mathrm{T}_{0}$ & $\mathrm{~T}_{1}$ & $\mathrm{~T}_{2}$ & $\mathrm{~T}_{3}$ \\
\hline Jagung kuning (\%) & 50,76 & 49,72 & 50,62 & 50,46 \\
\hline Bekatul (\%) & 41,98 & 39,10 & 41,87 & 41,73 \\
\hline Tepung bungkil kedelai (\%) & 2,93 & 4,54 & 2,92 & 2,91 \\
\hline Tepung ikan $(\%)$ & 3,99 & 6,30 & 3,97 & 3,96 \\
\hline Kapur $(\%)$ & 0,19 & 0,19 & 0,19 & 0,19 \\
\hline Premix vitamin* $(\%)$ & 0,15 & 0,15 & 0,15 & 0,15 \\
\hline Dl-metionin $(\%)$ & & & 0,09 & 0,19 \\
\hline L-lisin $\mathrm{HCl}(\%)$ & & & 0,19 & 0,42 \\
\hline Jumlah (\%) & 100,00 & 100,00 & 100,00 & 100,00 \\
\hline \multicolumn{5}{|l|}{$\underline{\text { Kandungan nutrien }}$} \\
\hline Energi termetabolis $(\mathrm{kcal} / \mathrm{kg}$ ) & 2987,31 & 2984,22 & 2979,06 & 2969,35 \\
\hline Protein kasar $(\%)$ & 13,20 & 15,00 & 13,16 & 13,12 \\
\hline Lemak kasar (\%) & 6,48 & 6,32 & 6,47 & 6,44 \\
\hline $\mathrm{Abu}(\%)$ & 7,18 & 7,64 & 7,16 & 7,13 \\
\hline Serat kasar $(\%)$ & 7,73 & 7,55 & 7,71 & 7,69 \\
\hline Metionin (\%) & 0,02 & 0,02 & 0,10 & 0,20 \\
\hline $\operatorname{Lisin}(\%)$ & 0,03 & 0,05 & 0,22 & 0,45 \\
\hline Kalsium (\%) & 1,26 & 1,41 & 1,25 & 1,25 \\
\hline Fosfor available (\%) & 0,60 & 0,58 & 0,60 & 0,60 \\
\hline
\end{tabular}

Keterangan: * setiap $10 \mathrm{~kg}$ mengandung vit. A $12000000 \mathrm{IU}, \mathrm{D}_{3} 2000000 \mathrm{IU}, \mathrm{E} 8000 \mathrm{IU}, \mathrm{K}_{3} 2000 \mathrm{mg}, \mathrm{B}_{1}$ $2000 \mathrm{mg}, \mathrm{B}_{2} 5000 \mathrm{mg}, \mathrm{B}_{6} 500 \mathrm{mg}, \mathrm{B}_{12} 12000 \mathrm{mg}$, C $25000 \mathrm{mg}$, Ca-D-pantothenate $6000 \mathrm{mg}$, niacin $40000 \mathrm{mg}$, choline chloride $10000 \mathrm{mg}$, methionine $30000 \mathrm{mg}$ dan lysine $30000 \mathrm{mg}$

\section{HASIL DAN PEMBAHASAN}

\section{Berat badan}

Data berat badan ayam kampung yang diperoleh menunjukkan bahwa berat badan fase pullet $(14-20$ minggu $)$ berbeda nyata $(\mathrm{P}<0,05)$ antar perlakuan $\mathrm{T}_{0}, \mathrm{~T}_{1}, \mathrm{~T}_{2}$, dan $\mathrm{T}_{3}$ (Tabel 2). Hasil penelitian menunjukkan bahwa penambahan protein kasar setara rekomendasi NRC yaitu $15 \%$ $\left(\mathrm{T}_{1}\right)$ tidak mampu meningkatkan berat badan jika dibandingkan dengan pakan sistem kafetaria. Suplementasi 0,09 \% DL-Metionin dan 0,19\% L- 
Lisin $\mathrm{HCl}$ dalam pakan $\left(\mathrm{T}_{2}\right)$ meningkatkan sebesar $5,05 \%$ berat badan akhir $(\mathrm{P}<0,05)$ jika dibandingkan dengan pakan standar protein NRC. Selanjutnya ditingkatkan 0,19\% DL-Metionin dan $0,42 \%$ L-Lisin $\mathrm{HCl}\left(\mathrm{T}_{3}\right)$, berat badan akhir masih meningkat sebesar $3,49 \% \quad(\mathrm{P}<0,05)$ jika dibandingkan dengan $\mathrm{T}_{2}$. Kecepatan pertumbuhan dan berat maksimal ayam dipengaruhi oleh keseimbangan nutrien dalam pakan. Martin et al. (2006) menyatakan bahwa asam amino dapat memodifikasi pertumbuhan otot dan jaringan lainnya.

Suplementasi asam amino kritis seperti metionin dan lisin bukan saja meningkatkan berat badan tetapi mempercepat pertumbuhan untuk mencapai maksimal. Cafe dan Waldroup (2006) menyatakan bahwa berat badan ayam dipengaruhi oleh ketersediaan dan keseimbangan asam amino dalam pakan yang dikonsumsinya. Asam amino metionin dan lisin berperan dalam pertumbuhan jaringan tubuh ayam (Wahju, 2003 dan Pesti et al., 2005). Pemberian asam amino metionin dan lisin dapat mempercepat pertumbuhan pada ayam kampung untuk mencapai pertumbuhan maksimal jika dibandingkan dengan pakan standar kafetaria maupun standar yang direkomendasikan NRC untuk ayam petelur. Pakan standar yang dihasilkan dari sistem kafetaria dan pakan standar protein NRC jika untuk perkembangan berat badan pada ayam kampung sudah memenuhi kebutuhan, tetapi untuk pertumbuhan maksimal, pakan standar kafetaria masih perlu direvisi dengan penambahan asam amino kritis yaitu metionin dan lisin. Si et al. (2001) menyatakan bahwa tingkat metionin dan lisin yang disarankan atau ditingkatkan lebih dari yang direkomendasikan NRC (1994) akan meningkatkan kinerja pertumbuhan dan konversi pakan. Grizard et al. (1995) melaporkan bahwa asam amino merangsang sintetis protein di hati, pankreas, limpa dan paru-paru yang selanjutnya bertindak sebagai mediator dalam jalur metabolisme untuk sintesis protein tubuh.

Tabel 2. Berat badan, berat organ dalam dan organ reproduksi ayam kampung fase pullet (14 - 20 minggu) yang diberikan pakan dengan standar kebutuhan nutrien yang berbeda

\begin{tabular}{lcrrrr}
\hline \multirow{2}{*}{ Uraian } & \multirow{2}{*}{\begin{tabular}{c} 
Umur \\
\cline { 3 - 5 }
\end{tabular}} & \multicolumn{1}{c}{$\mathrm{T}_{0}$} & \multicolumn{1}{c}{$\mathrm{T}_{1}$} & \multicolumn{1}{c}{$\mathrm{T}_{2}$} & \multicolumn{1}{c}{$\mathrm{T}_{3}$} \\
\hline Berat badan umur (g/ekor) & 20 & $1418,60 \pm 39,13^{\mathrm{c}}$ & $1431,59 \pm 32,26^{\mathrm{c}}$ & $1503,88 \pm 34,29^{\mathrm{b}}$ & $1556,41 \pm 29,33^{\mathrm{a}}$ \\
Berat hati dan empedu & & & & & \\
(g/ekor) & 20 & $22,44 \pm 1,52^{\mathrm{c}}$ & $21,79 \pm 1,32^{\mathrm{bc}}$ & $24,49 \pm 1,77^{\mathrm{ab}}$ & $25,93 \pm 0,77^{\mathrm{a}}$ \\
Berat pankreas (g/ekor) & 20 & $2,33 \pm 0,04^{\mathrm{c}}$ & $2,28 \pm 0,08^{\mathrm{c}}$ & $2,50 \pm 1,47^{\mathrm{b}}$ & $2,70 \pm 0,11^{\mathrm{a}}$ \\
Berat gizzard (g/ekor) & 20 & $25,31 \pm 1,00$ & $23,91 \pm 2,68$ & $25,38 \pm 0,66$ & $26,86 \pm 0,36$ \\
Berat testis (g/ekor) & 20 & $3,66 \pm 1,04^{\mathrm{b}}$ & $3,86 \pm 3,40^{\mathrm{b}}$ & $9,55 \pm 4,19^{\mathrm{a}}$ & $9,46 \pm 3,18^{\mathrm{a}}$ \\
Volume testis (ml/ekor) & 20 & $3,81 \pm 1,52^{\mathrm{b}}$ & $3,38 \pm 3,25^{\mathrm{b}}$ & $9,13 \pm 4,27^{\mathrm{a}}$ & $9,16 \pm 2,95^{\mathrm{a}}$ \\
Berat ovarium (g/ekor) & 20 & $1,12 \pm 0,92^{\mathrm{b}}$ & $1,32 \pm 0,23^{\mathrm{b}}$ & $3,14 \pm 0,83^{\mathrm{a}}$ & $4,61 \pm 2,00^{\mathrm{a}}$ \\
\hline
\end{tabular}

Keterangan: $\mathrm{T}_{0}=$ pakan standar kafetaria PK 13,20\% dan ME 2987,31 kcal/kg

$\mathrm{T}_{1}=$ pakan dengan standar protein kasar ayam petelur putih (NRC) PK $15 \%$

$\mathrm{T}_{2}=$ Pakan standar kafetaria + DL-Metionin 0,09\% + L-Lisin HCl 0,19\%

$\mathrm{T}_{3}=$ Pakan standar kafetaria + DL-Metionin 0,19\% + L-Lisin $\mathrm{HCl} 0,42 \%$

$\mathrm{a}, \mathrm{b}, \mathrm{c}$ superskrip pada baris yang sama menunjukkan perbedaan yang nyata $(\mathrm{P}<0,05)$

\section{Berat hati dan empedu}

Data berat hati dan empedu yang diperoleh dianalisis ragam yang menunjukkan bahwa pada fase pullet (14 - 20 minggu) berbeda nyata $(\mathrm{P}<0,05)$ antar perlakuan $\mathrm{T}_{0}, \mathrm{~T}_{1}, \mathrm{~T}_{2}$, dan $\mathrm{T}_{3}$ (Tabel 2). Berat hati dan empedu tertinggi pada $T_{3}$ $\left(25,93 \pm 0,77\right.$ g/ekor) dan terendah $\mathrm{T}_{1}(21,79 \pm ; 1,32$ g/ekor). Bunchasak dan Silapasorn (2005) melaporkan bahwa persentase berat hati ayam kampung akhir umur 20 minggu adalah 2,29\%.

Penambahan protein kasar yang setara rekomendasi NRC yaitu $15 \%\left(\mathrm{~T}_{1}\right)$ tidak mampu meningkatkan berat hati dan empedu ayam kampung jika dibandingkan dengan pakan sistem kafetaria. Suplementasi 0,09\% DL-Metionin dan $0,19 \%$ L-Lisin $\mathrm{HCl}$ dalam pakan $\left(\mathrm{T}_{2}\right)$ meningkatkan sebesar $9,13 \%$ berat hati dan empedu $(\mathrm{P}<0,05)$ jika dibandingkan dengan pakan standar pakan kafetaria. Selanjutnya ditingkatkan sebesar $0,19 \%$ dl-metionin dan $0,42 \%$ l-lisin $\mathrm{HCl}\left(\mathrm{T}_{3}\right)$, berat hati dan empedu masih meningkat sebesar 19,00\% $(\mathrm{P}<0,05)$ jika dibandingkan dengan pakan standar protein NRC $(\mathrm{P}<0,05)$, tetapi peningkatan ini berbeda tidak nyata untuk $\mathrm{T}_{2}$. Semakin bertambah berat ayam maka berat hati dan empedu juga meningkat. Resnawati (2002) menyatakan bahwa perkembangan organ dalam berkorelasi positif dengan pertumbuhan ayam. Berat hati mempunyai hubungan linear dengan berat badan dalam merespon suplementasi asam amino metionin dan lisin (Woyengo et al., 2011). 
Suplementasi DL-Metionin dan L-Lisin $\mathrm{HCl}$ dalam pakan mengakibatkan peningkatan sintesis protein jaringan tubuh untuk pertumbuhan termasuk organ dalam. Ukuran berat, konsistensi dan warna hati dipengaruhi oleh umur, bangsa dan status nutrisi ternak (Sumiati et al., 2002).

\section{Berat pankreas}

Data berat pankreas yang diperoleh dianalisis ragam yang menunjukkan bahwa pada fase pullet (14 - 20 minggu) berbeda nyata $(\mathrm{P}<0,05)$ antar perlakuan $\mathrm{T}_{0}, \mathrm{~T}_{1}, \mathrm{~T}_{2}$, dan $\mathrm{T}_{3}$ (Tabel 2). Berat pankreas tertinggi pada $T_{3}(2,70 \pm 0,11$ g/ekor) dan terendah $\mathrm{T}_{1}(2,28 \pm 0,08$ g/ekor $)$. Sturkie (2000) melaporkan bahwa berat pankreas berkisar antara 2,5 - $4 \mathrm{~g}$ pada ayam dewasa. Penambahan protein kasar yang setara rekomendasi NRC yaitu $15 \%\left(\mathrm{~T}_{1}\right)$ tidak mampu meningkatkan berat pankreas jika dibandingkan dengan pakan sistem kafetaria. Suplementasi 0,09 $\%$ DL-Metionin dan 0,19\% L-Lisin $\mathrm{HCl}$ dalam pakan $\left(\mathrm{T}_{2}\right)$ meningkatkan sebesar $7,29 \%$ berat pankreas $(\mathrm{P}<0,05)$ jika dibandingkan dengan pakan standar kafetaria. Selanjutnya ditingkatkan sebesar 0,19\% DL-Metionin dan 0,42\% L-Lisin $\mathrm{HCl}\left(\mathrm{T}_{3}\right)$, berat pankreas masih meningkat sebesar $8,00 \%$ jika dibandingkan dengan $\mathrm{T}_{2}(\mathrm{P}<0,05)$. Feng et al. (2007) menjelaskan bahwa pakan unggas yang mengandung protein dengan penambahan asam amino sintesis cenderung akan membentuk pembesaran pankreas. Pembesaran pankreas tersebut akan meningkatkan sekresi tripsin yang akan berfungsi untuk mencerna protein. Peningkatan bobot pankreas merupakan salah satu bentuk adaptasi untuk mencukupi kebutuhan enzim pencernaan yang meningkat. Tingginya berat pankreas pada penelitian ini disebabkan oleh adanya perbedaan kerja pankreas dalam mensekresikan enzim-enzim pencernaan untuk mencerna pakan yang dikonsumsi.

\section{Berat gizzard}

Data berat gizzard yang diperoleh dianalisis ragam yang menunjukkan bahwa pada fase pullet (14 - 20 minggu) berbeda tidak nyata antar perlakuan $\mathrm{T}_{0}, \mathrm{~T}_{1}, \mathrm{~T}_{2}$, dan $\mathrm{T}_{3}$ (Tabel 2). Rata-rata berat gizzard pada fase pullet adalah $25,37 \pm 1,71$ g/ekor. Pond et al. (1995) melaporkan bahwa persentase berat gizzard ayam adalah 1,6-2,3\% dari bobot hidup. Zhou et al. (1990); Siri et al. (1992) menyatakan bahwa semakin banyak jumlah pakan yang dikonsumsi makin aktif kegiatan organ pencernaan untuk mencerna sehingga dapat merangsang pertumbuhan organ pencernaan. Bobot badan dan jumlah pakan yang dikonsumsi berhubungan erat dengan kapasitas pertumbuhan organ pencernaan (Shapiro dan Nir, 1995; Suthama, 2005).
Zhou et al. (1990) menyatakan bahwa kebutuhan nutrien pada periode pertumbuhan atau perkembangan awal setelah menetas tergantung pada kemampuan adaptasi organ pencernaan berdasarkan atas morfologi dan fungsi. Selanjutnya dinyatakan status nutrien dan pola pakan dapat memodifikasi berat dan fungsi organ pencernaan. Peningkatan nutrien dalam pakan yang dikonsumsi merangsang pertumbuhan organ pencernaan, meningkatkan kapasitas pencernaaan dan absorbsi nutrien (Choct and Kocher, 2000).

\section{Berat dan volume testis}

Berat dan volume testis ayam kampung pada umur 20 minggu menunjukkan perbedaan yang nyata $(\mathrm{P}<0,05)$ antar perlakuan $\mathrm{T}_{0}, \mathrm{~T}_{1}, \mathrm{~T}_{2}$, dan $\mathrm{T}_{3}$ (Tabel 2). Berat dan volume testis tertinggi pada perlakuan yang mendapat suplementasi dlmetionin dan 1-lisin $\mathrm{HCl}$. Tadondjou et al. (2013) menyatakan bahwa berat testis ayam kampung pada umur 13 minggu dan 20 minggu adalah 5,73 g/ekor dan 12,04 - 15,35 g/ekor. Penambahan protein kasar setara rekomendasi NRC yaitu $15 \%$ $\left(\mathrm{T}_{1}\right)$ tidak mampu meningkatkan berat dan volume testis jika dibanding dengan pakan sistem kafetaria. Suplementasi 0,09\% DL-Metionin dan $0,19 \%$ L-Lisin $\mathrm{HCl}$ dalam pakan $\left(\mathrm{T}_{2}\right)$ meningkatkan sebesar $147,41 \%$ berat testis $(\mathrm{P}<0,05)$ jika dibanding dengan pakan standar protein NRC. Selanjutnya ditingkatkan sebesar $0,19 \%$ DL-Metionin dan 0,42\% L-Lisin $\mathrm{HCl}\left(\mathrm{T}_{3}\right)$ tidak mempengaruhi berat testis jika dibanding dengan $\mathrm{T}_{2}$.

Volume testis pada akhir fase pullet juga meningkat pada pakan dengan suplementasi metionin dan lisin yaitu $140,42 \%$ jika dibandingkan dengan pakan standar kafetaria $(\mathrm{P}<0,05)$. Suplementasi DL-Metionin dan L-Lisin $\mathrm{HCl}$ menyebabkan terjadi keseimbangan nutrien dalam pakan. Tadondjou et al. (2013) menyatakan bahwa keadaan lingkungan dan keseimbangan nutrien pakan mempengaruhi hipotalamus mensekresikan hormon yang relevan seperti Follicle Stimulating Hormone (FSH) dan Luteinizing Hormone (LH) untuk perkembangan epitel seminiferus dan proliferasi spermatogonia.

\section{Berat ovarium}

Dari data berat ovarium, tampak bahwa pada akhir fase pullet menunjukkan perbedaan yang nyata $(\mathrm{P}<0,05)$ antar perlakuan $\mathrm{T}_{0}, \mathrm{~T}_{1}, \mathrm{~T}_{2}$, dan $\mathrm{T}_{3}$ (Tabel 2). Pada akhir fase pullet, berat ovarium tertinggi pada $\mathrm{T}_{3}(4,61 \pm 2,00 \mathrm{~g} / \mathrm{ekor})$ dan terendah $\mathrm{T}_{1} \quad(1,12 \pm 0,92 \mathrm{~g} / \mathrm{ekor})$. Menurut Bunchasak dan Silapasorn (2005) berat ovarium ayam kampung umur $24-44$ minggu adalah 1,51 $-2,49 \%$ dari berat hidup. 
Penambahan protein kasar yang setara rekomendasi NRC yaitu $15 \%\left(\mathrm{~T}_{1}\right)$ tidak mampu meningkatkan berat ovarium jika dibandingkan dengan pakan standar kafetaria. Suplementasi 0,09\% dl-metionin dan 0,19\% 1-lisin $\mathrm{HCl}$ dalam pakan $\left(\mathrm{T}_{2}\right)$ meningkatkan sebesar $137,88 \%$ berat ovarium $(\mathrm{P}<0,05)$ jika dibandingkan dengan pakan standar protein NRC. Selanjutnya ditingkatkan sebesar $0,19 \%$ dl-metionin dan $0,42 \%$ 1-lisin $\mathrm{HCl}\left(\mathrm{T}_{3}\right)$, berat ovarium tidak meningkat lagi jika dibandingkan dengan $\mathrm{T}_{2}$. Dalam hal sistem reproduksi, Alli dan Ayorinde (2013) menyatakan bahwa pada pakan dengan $20 \%$ protein kasar dan $2.750 \mathrm{kcal} / \mathrm{kg} \mathrm{ME}$ meningkatkan kinerja reproduksi seperti umur bertelur pertama, jumlah telur, massa telur dan produksi hen/day selama 20 - 52 minggu umur ayam. Bunchasak dan Silapasorn (2005) menemukan bahwa peningkatan asam amino metionin dalam pakan rendah protein meningkatkan bobot ovarium dan saluran oviduk dari sejak bertelur pada umur 24 minggu sampai 44 minggu ayam komersial (Isa-coklat).

\section{SIMPULAN}

Suplementasi dl-metionin sebesar 0,19\% dan l-lisin $\mathrm{HCl} 0,42 \%$ pada pakan standar kafetaria dengan kandungan protein $13,20 \%$ meningkatkan kinerja berat badan, berat hati dan empedu, berat pankreas, berat dan volume testis dan berat ovarium ayam kampung pada umur 20 minggu.

\section{DAFTAR PUSTAKA}

Bronstein, S. and B. Lepstein. 1975. The replacement of some of soybean meal by first limiting amino acids in practical broiler diets. I The value of special suplementation of chicks diets with methionine and lysine. British Poultry Science. 16: $177-188$.

Bunchasak, Ch. and T. Silapasorn. 2005. Effectsof adding methionine in lowprotein diet on production performance, reproductive organs and chemical liver composition of laying hens under tropical conditions. Int. J. Poultry Sci. 4(5): 301308.

Cafe, M.B. and P. W. Waldroup. 2006. Interactions between levels of methionine and lysine in broiler diets changed at typical industry intervals. Int. J. Poultry Sci. 5(11): 1008-1015.

Choct, M. and A. Kocher. 2000. Non starch carbohydrates: digestion and its secondary effects in monogastrics. Proceedings of the Nutrition Society of Australia. 24: 31-38.

Feng, L., X. Liu, R. Xu, Y.Z. Wang and J.X. Liu. 2007. Effects of fermented soybean meal on digestive enzyme activities and intestinal morphology in broiler. J. Poultry Sci. 86: 1149-1154.

Grizard J., D. Dardevet, I. Papet, L. Mosoni, M.P. Patureau, D. Attaix, I. Tauveron, D. Bonin and M. Arnal. 1995. Nutrient regulation of skeletal muscle protein metabolism in animals. The involvement of hormones and substrates. Nutrition Research Reviews. (8): 67-91.

Kartikasari, L.R., Soeparno dan Setiyono. 2001. Komposisi kimia dan studi asam lemak daging dada ayam broiler yang mendapat suplementasi metionin pada pakan berkadar protein rendah. Bul. Pet. 25 (1): $33-39$.

Leeson, S., and J.D. Summers. 2001. Nutrition of The Chicken 4th Ed. University Book, Quelph, Ontorio, Canada.

Lisnahan, Ch. V. 2018. Penentuan kebutuhan nutrien ayam kampung fase pertumbuhan yang dipelihara secara intensif dengan metode kafetaria. Disertasi. Fakultas Peternakan Universitas Gadjah Mada. Yogyakarta.

Martin,V. R., P.A. Geraert and R. Ferrer. 2006. Conversion of the methionine hydroxyl analogue DL-2-hydroxy-(4-methylthio) Butanoic acid to sulfur-containing amino acids in the chicken small intestine. Poultry Sci.. 85: 1932-1938.

National Research Council. 1994. Nutriens Requairement of Poultry. Eight Revised Ed. National Academy Press. Washington D.C.

Pesti, G. M., R. I. Bakalli, J. P. Driver, A. Atencio, and E. H. Foster. 2005. Poultry Nutrition and Feeding. Department of Poultry Science University of Georgia. Trafford Publishing. Athens.

Pond, W.G., D.C. Church and K.R. Pond.1995. Basic Animal Nutrition and Feeding. $4^{\text {th }}$ ed. John Wiley and Sons. New York.

Resnawati, H. 2002. Produksi karkas dan organ dalam ayam pedaging yang diberi ransum mengandung tepung cacing tanah (Lumbricus rubbellus). Seminar Nasional Teknologi Peternakan dan Veteriner. Balai Penelitian Ternak. Bogor.

Selle, P.H., V. Ravindran, G. Ravindran and W.L. Bryden. 2007. Effects of dietary lysine and microbial phytase on growth performanve and nutrient utilization of broiler chickens. 
Asian-Australansian J. Anim. Sci. 20(7): 1100-1107.

Shapiro, F. And I. Nir. 1995. Stunting syndrome in broilers: Effect of age and exogenous amylase and protease on performance, development of the digestive tract, digestive enzyme activity, and apparent digestibility. Poultry Science. 74: 20192028.

Si, J., C.A. Fritts, D.J. Burnham and P.W. Waldroup. 2001. Relationship of dietary lysine level to the concentration of all essential amino acids in broiler diets. Poultry Science. 80: 1472-1479.

Siri, S., S. Tabioka and I. Tasaki. 1992. Effect of dietary fiber on growth performance, development of intestinal organs, protein and energy utilization, and lipid content of growing chicks. Japan Poultry Science. 20: $106-113$.

Sturkie. 2000. Avian physiology. Fifth Edition. Edited by : G. Causey Whittow. Departemen of Physiology. Jhon A. Burns School of Medicine University of Haway at Manoa. Hawaii. Academic Press

Sumiati, W. Hermana dan A. Aliyani. 2002. Persentase berat karkas dan organ dalam ayam broiler yang diberi tepung daun talas (Colocasia esculenta (L.) Schoot) dalam ransumnya. Media Peternakan. 26 (1): 410.

Suthama, N. 2005. Kapasitas ribosomal saluran pencernaan pada ayam Kedu. J. Peng. Pet. Trop. 30(1): 7-12.

Tadondjou, C. D. A., F. Ngoula, J. R. Kana, H. F. Defang, H. K. Mube and A. Teguia. 2013. Effect of dietary energy level on body weight, testicular development and semen quality of local barred chicken of the western highlands of Cameroon. Advances in Reproductive Sciences. 1(3): 38-43.

Wahju, J. 2003. Ilmu Nutrisi Unggas. Gajah Mada University Press. Yogyakarta.

Woyengo, T. A., E. Kiarie and C. M. Nyachoti. 2011. Growth performance, organ weights, and blood parameters of broilers fed diets containing expeller-extracted canola meal. Poultry Science. 90(11) 2520-2527.

Zhou, Z.-X., Y. Isshiki, K. Yamauchi and Y. Nakahiro. 1990. Effects of force-feeding and dietary cereals on gastrointestinal size, intestinal absorptive ability and endogenous Nitrogen in ducks. British Poultry Science. 31: 307-317. 